\title{
Når jorden går amok
}

Anmeldt af geolog Ulla V. Hjuler, GeologiskNyt

De sidste par år har været rystet af flere voldsomme naturkatastrofer. Tsunamien i Det Indiske Ocean i julen 2004 udløst af et af de kraftigste jordskælv nogensinde. Orkanen Katrina, der raserede New Orleans sidst $i$ august 2005. I oktober samme år ramte et voldsomt jordskælv Pakistan. Men der har været en hel del dødbringende katastrofer i Jordens historie.

"Når jorden går amok" er en spændende og informativ bog, der på vellykket vis formår at blande øjenvidneberetninger og fakta. Samtidig tager den fat på glemte eller måske ligefrem ukendte kæmpekatastrofer, som fandt sted for inden for nyere tid eller for mange, mange år siden.

\section{Inddelinger i 6 hovedafsnit}

Bogen er inddelt i 6 kapitler: ocean, jord, skælv, tsunami, vulkan og orkan. I bogens slutning findes et kort tillæg over 10 andre naturkatastrofer.

Første kapitel, ocean, drejer sig om tsunamien i Det Indiske Ocean. Forfatteren serverer først en række geologiske facts og oplysninger om hændelsesforløbet - primært om Sumatra - beskrivelser og forklaringer følger senere i samme kapitel om de andre berørte områder. Ind imellem er der beretninger om personer, der på heldig vis overlevede den voldsomme hændelse. Herefter følger en meget spændende og intens beretning fra en dansk familie, der overlevede tumulterne i de frådende vandmasser.

Kapitlet er levende illustreret med en del gribende billeder og et relevant, simpelt kort, der viser de berørte områder. Noget der i øvrigt findes i alle kapitlerne, er de til tider meget stærke fotos, der så sandelig gør indtryk på læseren. I knapt så omfangsrig grad findes der oplysende illustrationer og tabeller - lidt flere kort og principskitser ville næppe have været af vejen.

\section{Jord og skælv}

Kapitlet om jord er relativt kort og nærmest en intro til det efterfølgende kapitel "skælv". Læseren sættes ind i de væsent-

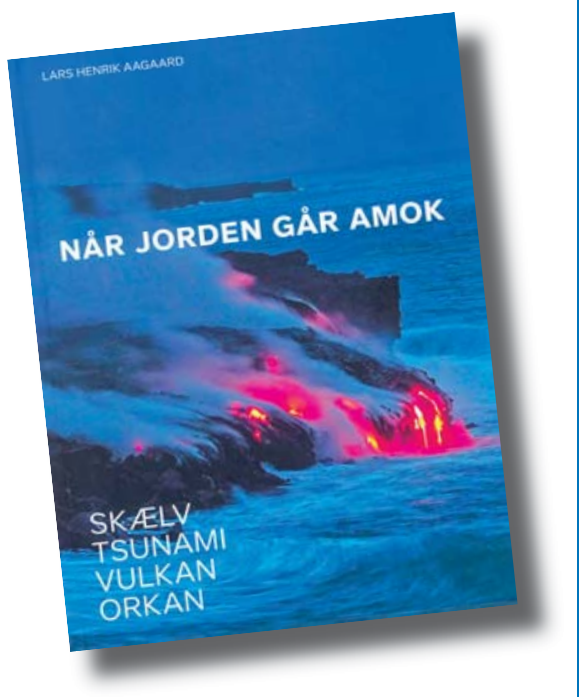

bora, Mount St. Helens m.fl. er selvfølgelig også nævnt, og kapitlet slutter af med et afsnit om supervulkaner.

Bogen afsluttes i den "luftige" ende med kapitlet "orkan", hvor man naturligvis ikke kommer uden om hoben af tropiske orkaner i USA sidste år.

\section{Solidt håndværk}

Det gode ved denne bog er, at den også tager fat på mindre eller helt glemte katastrofer, hvoraf nogle jo har været kolosale i omfang! Danmark er også nævnt i flere sammenhænge, selvom det jo ikke er et land med fæle naturkatastrofe-traditioner, men derfor er det alligevel interessant at se landet $i$ et større perspektiv.

Bogen bliver aldrig sensationsagtig, selvom emnet godt kunne give anstød til det - og forfatteren måske kunne falde i med sin journalistiske baggrund, men det gør han ikke, og bogen er en glimrende kombinatione af faglig indsigt, historiske oplysninger og øjenvidneberetninger. Og så er den illustreret med nogle rigtigt flotte billeder, der gør, at man får lyst til at bladre og blot se illustrationerne!

ligste grundlag for et jordskælv - Jordens opbygning, kontinenternes drift og selve drivkraften.

Herefter er man så rustet til kapitlet om skælv, der ikke straks tager fat på det voldsomme skælv i Pakistan, men i stedet fører læseren tilbage i tiden til skælvet i Tangshan i Kina i 1976, et jordskælv der tilsyneladende er ukendt for mange mennesker, selvom mere end 250.000 mennesker omkom!

Adskillige historiske jordskælv behandles, og Pakistan-skælvet sidste år er naturligvis også med - interessante oplysninger som fx listen over de 10 kraftigste jordskælv og listen med de 10 mest dødbringende skælv - der bestemt ikke følges ad - findes også i teksten.

\section{Tsunami, vulkan og orkan}

Tsunami-kapitlet er ikke så langt - en stor del af krudtet blev også brugt i ocean-kapitlet - men der bliver plads til nogle historiske beretninger og gisninger om eventuelt kommende tsunamier.

I næste kapitel hvirvles læseren ind i beretninger om Islands talrige vulkaner. Island ligger midt i en spredningszone, hvilket gør øen ret så eksplosiv - dette har medført mange store udbrud, som man kan læse om i dette kapitel.

Udbruddene på Santorini, Vesuv, Tam-
“Når jorden går amok" af Lars Henrik Aagaard, 256 sider gennemillustreret i farver. Jyllands-Postens Forlag, 2006. Vejledende pris 269 kr. ISBN: 87-7692-023-2. 